\title{
Effects of Cooling Rate on the Microstructure and Tensile Strength of
}

\author{
A356 Alloy Wheels \\ Zhenbang Liu ${ }^{1, a^{*}}$, Li zhou ${ }^{1, b}$ and Guowei Li ${ }^{2, c}$ \\ ${ }^{1}$ School of Materials Science and Engineering, Beihang University, Beijing 100191, China \\ ${ }^{2}$ SMX Dicastal Wheel Manufacture Company, Henan 472000, China \\ a zhenbangliu@buaa.edu.cn \\ bzhoul@buaa.edu.cn \\ 'guowei_lee@126.com
}

Key words: Aluminum alloys; Cooling rate; Microstructure; Tensile strength

Abstract:In this work, the effects of cooling rate on the microstructure and tensile strength of A356 wheels during solidification were studied. Four cooling methods, including air cooling, wind cooling and two different water coolings, were a used to control the cooling rate of spoke. Comparing with the air cooling and wind cooling, at higher water cooling rates, the iron phase appeared from the peritectic-type reaction, which transformed from the previous $\beta-\mathrm{Al}_{5} \mathrm{FeSi}$ phase to $\pi-\mathrm{Al}_{8} \mathrm{Mg}_{3} \mathrm{FeSi}_{6}$ phase. Besides, as cooling rate increased from $0.69{ }^{\circ} \mathrm{C} / \mathrm{s}$ to $1.95{ }^{\circ} \mathrm{C} / \mathrm{s}$, the secondary dendritic arm spacing (SDAS) declined from $44.41 \mu \mathrm{m}$ to $31.86 \mu \mathrm{m}$. The UTS and YS could reach 225.27Mpa and $143.02 \mathrm{Mpa}$ in the water cooling with the minimum water flow velocity $(16 \mathrm{~L} / \mathrm{h})$, respectively.

\section{Introduction}

Al-Si-Mg casting alloys have been widely used in automotive and aerospace industries [1]. In particular, A356 alloys has been used extensively in automotive parts, such as wheels, chassis, and models [2,3].

The microstructure of A356 alloy wheel is composed of $\alpha-\mathrm{Al}$ dendrites, eutectic silicon and Fe-rich compound. There are some main Fe-rich phases in the Al-Si alloys: $\alpha-\mathrm{Al}_{8} \mathrm{Fe}_{2} \mathrm{Si}$ (possibly $\left.\alpha-\mathrm{Al}_{12} \mathrm{Fe}_{3} \mathrm{Si}_{2}\right), \alpha-\mathrm{Al}_{15} \mathrm{Fe}_{3} \mathrm{Si}_{2}, \beta-\mathrm{Al}_{5} \mathrm{FeSi}, \beta-\mathrm{Al}_{9} \mathrm{Fe}_{2} \mathrm{Si}_{2}, \delta-\mathrm{Al}_{4} \mathrm{FeSi}_{2}$ and $\pi-\mathrm{Al}_{8} \mathrm{Mg}_{3} \mathrm{FeSi}_{6}$ [4,5]. Among them, large $\beta-\mathrm{Al}_{5} \mathrm{FeSi}$ phase is considered as the most harmful factor for the mechanical properties of alloys. Therefore, the morphology of the $\beta-\mathrm{Al}_{5} \mathrm{FeSi}$ phase should be controlled in order to obtain comprehensive properties. For a given alloy, especially for the aluminum alloy wheels, the cooling types affect the distribution of Fe-rich phase and the structure of dendrites and eutectic.

Cooling rate can influence the temperature gradient and solidification rate, and is one of the most important factors which affect microstructure and mechanical properties of alloys [6,7,8]. Aluminum alloy wheels used in automobile are generally fabricated by low-pressure casting process where air cooling or water cooling is generally adopted as the cooling method. Increasing the cooling rate will improve the mechanical performance of the wheels during the cooling process. However, there lacks quantitative studies about the exact cooling rate that can produce high quality aluminum alloy wheels. In this work, four cooling methods, including air cooling, wind cooling, 
and two different water coolings were applied in the low pressure casting process of A356 alloy wheels. The influences of different cooling rates on microstructure and mechanical properties were investigated and discussed.

\section{Experimental Methods}

\section{Preparation of specimens}

The wheels of A356 alloy, supplied by the SMX Dicastal Wheels Manufacture Company, were fabricated by low pressure die casting. The chemical compositions of alloy were shown in Table 1 . The material was melted into models at $720^{\circ} \mathrm{C}$. The melt was modified with Al-10Sr master alloy and degassed with nitrogen. Then, Al-5Ti-1B rod grain refinement was added into the melt. The wheels were cooled by four types of cooling methods, namely air cooling, wind cooling, minimum water cooling and maximum water cooling, marked as sample 1, sample 2, sample 3 and sample 4, respectively. Table 2 shows the parameters of four cooling methods. The wind flow velocity was 85 $\mathrm{m}^{3} / \mathrm{h}$. For the water cooling method, the minimum water cooling represented that water flow velocity was $16 \mathrm{~L} / \mathrm{h}$, while the maximum water cooling represented that water flow velocity was 30 $\mathrm{L} / \mathrm{h}$. The mold cooling schematic diagram was shown in Fig. 1. Then the as-cast wheels obtained by four different cooling types were subjected to the T6 heat treatment (solution treatment at $540^{\circ} \mathrm{C}$ for $6 \mathrm{~h}$ and aging at $170^{\circ} \mathrm{C}$ for $6 \mathrm{~h}$ ).

Table 1 Chemical composition of A356 alloy [wt. \%]

\begin{tabular}{cccccccccccc}
\hline Alloy & $\mathrm{Al}$ & $\mathrm{Si}$ & $\mathrm{Mg}$ & $\mathrm{Ti}$ & $\mathrm{Sr}$ & $\mathrm{Fe}$ & $\mathrm{Ga}$ & $\mathrm{Cu}$ & $\mathrm{Mn}$ & $\mathrm{Zn}$ & Other \\
\hline A356 & Balance & 6.64 & 0.292 & 0.132 & 0.015 & 0.112 & 0.0148 & $\leq 0.001$ & 0.004 & 0.023 & $\leq 0.15$ \\
\hline
\end{tabular}

Table 2 Technological parameters of different cooling types

\begin{tabular}{lcccc}
\hline & Sample 1 & Sample 2 & Sample 3 & Sample 4 \\
\hline Cooling types & Air & Wind & Minimum water & Maximum water \\
Medium flow & - & $85\left[\mathrm{~m}^{3} / \mathrm{h}\right]$ & $16[\mathrm{~L} / \mathrm{h}]$ & $30[\mathrm{~L} / \mathrm{h}]$ \\
\hline
\end{tabular}

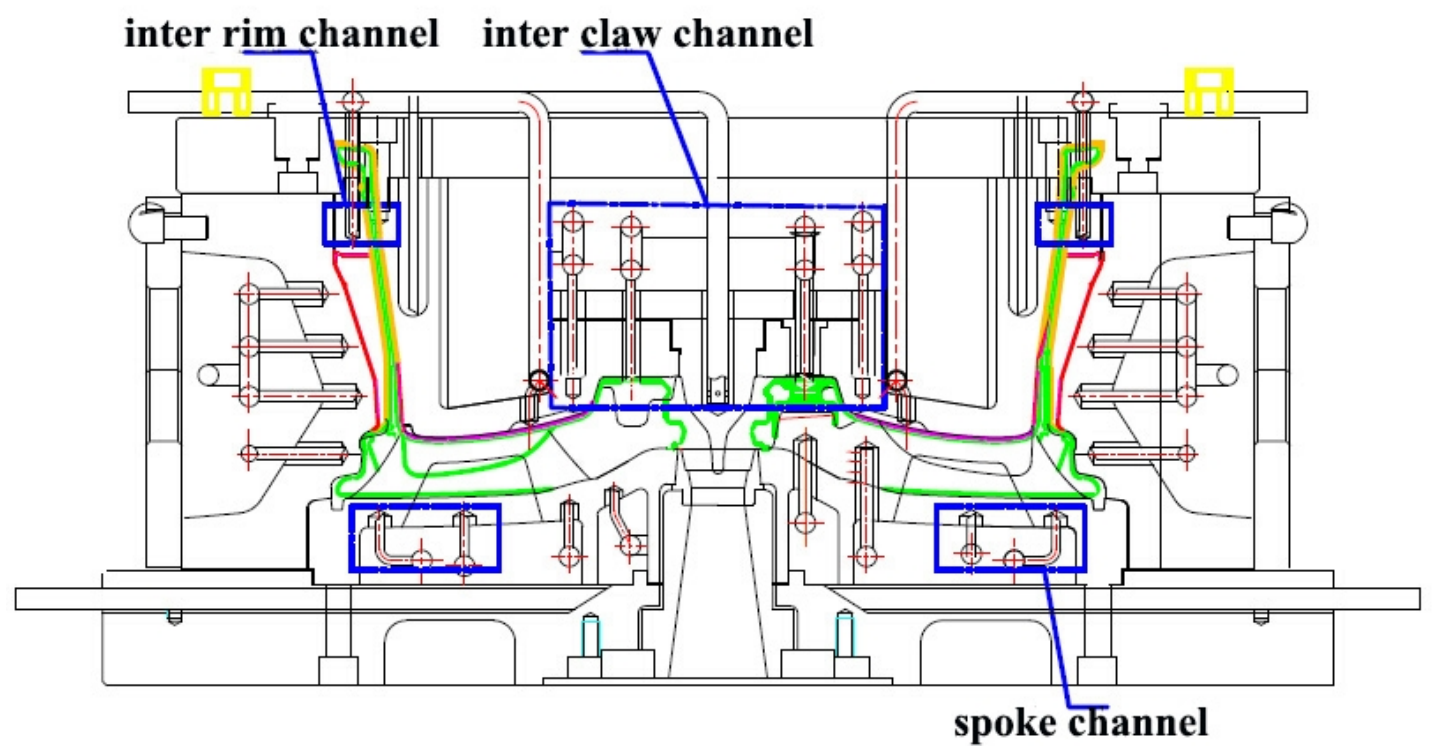

Fig.1. Cooling schematic diagram of the mold

\section{Microstructure analysis}

The microstructural features of the samples after T6 heat treatment were examined with scanning electron microscopy (SEM, JSM6010, Japan). Phases were identified by using an electron prober microstructure analyzer (EPMA, JX8100, Japan), equipped with energy dispersive spectroscope 
(EDS). The metallographic examination was carried out using the optical microscope equipped with an image analysis software package (Image-pro plus).

In this work, secondary dendrite arm spacing (SDAS) was measured by identifying the groups of secondary dendrite cells within the pictures of the image analyzer. SDAS was calculated as follows:

$\mathrm{SDAS}=\mathrm{L} / \mathrm{nM}$.

where $\mathrm{L}$ was the length of the line drawn from edge to edge of the measured cells, $M$ was the magnification and $\mathrm{n}$ was the number of dendrite cells [7,9].

In order to evaluate the structure change of the intermetallic phases, the average size of Fe-rich phases were calculated and more than 300 particles were measured for each sample.

\section{Mechanical tests}

The stain was measured over a measuring length of $42 \mathrm{~mm}$ and diameter of $6 \mathrm{~mm}$, with an extensometer attached to the sample. Four tensile specimens of spoke (air cooling, wind cooling, two different water coolings) were machined, respectively.

Tensile test was performed on samples drawn from the spoke of the wheels as shown in Fig.2. The tests were carried out using a tensile testing machine (Instron,8801,UK) with a speed of 1 $\mathrm{mm} / \mathrm{min}$ at room temperature to obtain ultimate tensile strength (UTS), yield strength (YS) and percent elongation $(\% \mathrm{E})$.

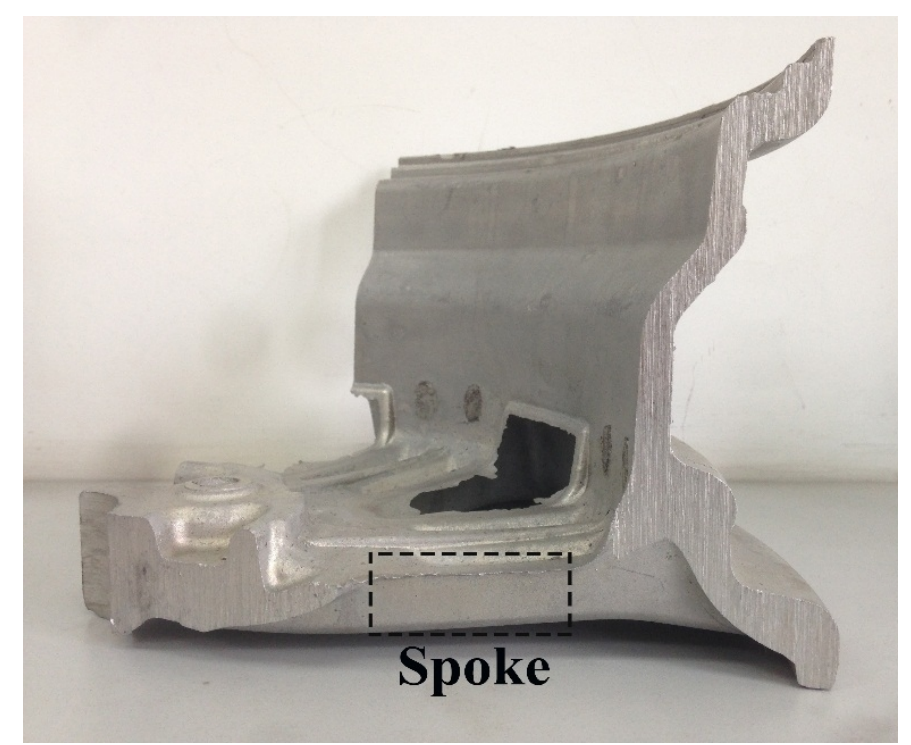

Fig.2. Position of the spoke in the wheels analysed

\section{Results}

\section{Microstructure}

Fig.3 illustrates the microstructure of four samples. According to Fig.3, the typical microstructure of the spoke in the A356 alloy wheel mainly consists of $\alpha$-Al dendrites, eutectic Si and Fe-rich phases. To be specific, there is a large area of the eutectic silicon enrichment in sample 3. In sample 1 and sample 2 , the major intermetallic phase is needle-shaped $\beta-\mathrm{Al}_{5} \mathrm{FeSi}$ phase. However, another Fe-rich phase occurs in the sample 3 and sample 4, as shown in Figures 3(c) and 3(d). The Fe-rich phase is like fish bones and located at $\alpha$-Al interdendrites and the area between eutectic silicon and $\alpha$-Al dendrites. The EDS of sample 3 and sample 4, as shown in Table 3, imply that the Fe-rich phase is $\pi-\mathrm{Al}_{8} \mathrm{Mg}_{3} \mathrm{FeSi}_{6}$. The $\pi$-Fe phase in the sample 3 has longer length than that in the sample 4.

As the previous literature reported [10,11], SDAS in the A356 alloys could be fit well with the 
following empirical equation [12],

$$
\mathrm{SDAS}=39.4 \mathrm{R}^{-0.317} \text {. }
$$

where the unit of SDAS is in $\mu \mathrm{m}$ and $\mathrm{R}$ is in ${ }^{\circ} \mathrm{C} / \mathrm{s} . \mathrm{R}=(\mathrm{dT} / \mathrm{dt})$ represents the cooling rate of the primary aluminum dendrite cells during solidification. Combined the equation (1) and (2), SDAS values and cooling rates of four samples calculated and shown in Table 4. The results show that from sample 1 to sample 4, SDAS decreases and cooling rate increases. The size of Fe-rich phases declines as the cooling rate increases, as shown in Fig.4.

Table 3 Average compositions of Fe-rich intermetallic phases in sample 3 and sample 4 measured by EDS analysis [at. \%]

\begin{tabular}{ccc}
\hline Element & Sample 3 & Sample 4 \\
\hline $\mathrm{Mg}$ & 16.64 & 14.66 \\
$\mathrm{Al}$ & 48.93 & 52.99 \\
$\mathrm{Si}$ & 28.68 & 27.24 \\
$\mathrm{Fe}$ & 5.75 & 5.10 \\
\hline
\end{tabular}
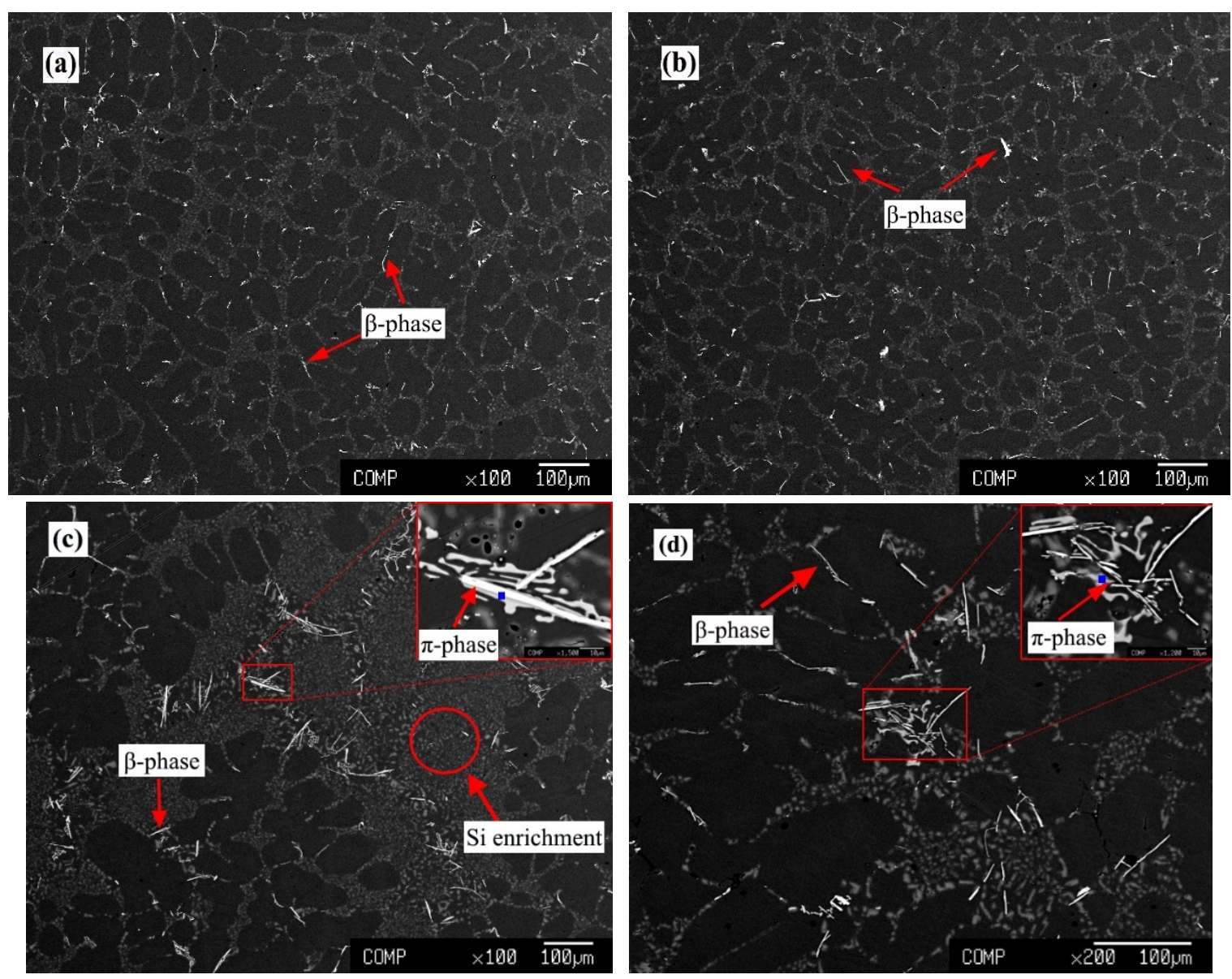

Fig.3. Microstructures of samples cooled by four cooling types: (a) sample 1, (b) sample 2, (c) sample 3, (d) sample 4 
Table 4 Average SDAS and cooling rate of samples

\begin{tabular}{cccc}
\hline Sample & $\begin{array}{c}\text { Cooling } \\
\text { method }\end{array}$ & $\begin{array}{c}\text { SDAS } \\
{[\mu \mathrm{m}]}\end{array}$ & $\begin{array}{c}\text { Cooling } \\
\text { Rate }\left[{ }^{\circ} \mathrm{C} / \mathrm{s}\right]\end{array}$ \\
\hline 1 & air cooling & 44.41 & 0.69 \\
2 & wind cooling & 41.12 & 0.87 \\
3 & minimum water cooling & 38.16 & 1.11 \\
4 & maximum water cooling & 31.86 & 1.95 \\
\hline
\end{tabular}

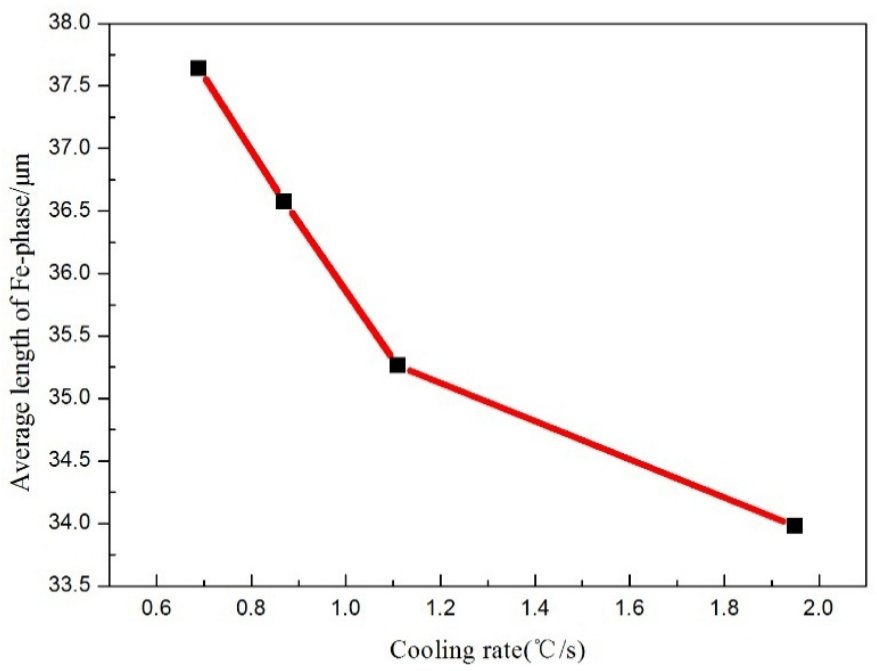

Fig.4. Average length of Fe-phases as a function of cooling rates

\section{The tensile properties of A356 alloy wheel}

The tensile properties of four samples are shown in Fig.5. The UTS of samples increase first and then decrease with the increase of the cooling rate. Within the range of studied cooling rates, the mean UTS and YS of the A356 alloy are $220 \pm 5 \mathrm{MPa}, 135 \pm 10 \mathrm{MPa}$, respectively.

The cooling rate of sample 3 is $1.11^{\circ} \mathrm{C} / \mathrm{s}$, and the UTS and YS of spoke area reached the maximum values of $225.27 \mathrm{MPa}$ and $143.02 \mathrm{MPa}$, respectively. But the elongation reached the minimum value of $5.91 \%$. In contrast, the UTS and YS of spoke area have the lowest values at the cooling rate of $1.95^{\circ} \mathrm{C} / \mathrm{s}$ in sample $4,212.59 \mathrm{MPa}$ and $126.84 \mathrm{MPa}$, respectively, and the elongation is $6.37 \%$. Overall, the best ultimate tensile strength and yield strength have been obtained in the sample 3, and the best elongation obtained in the sample 2.
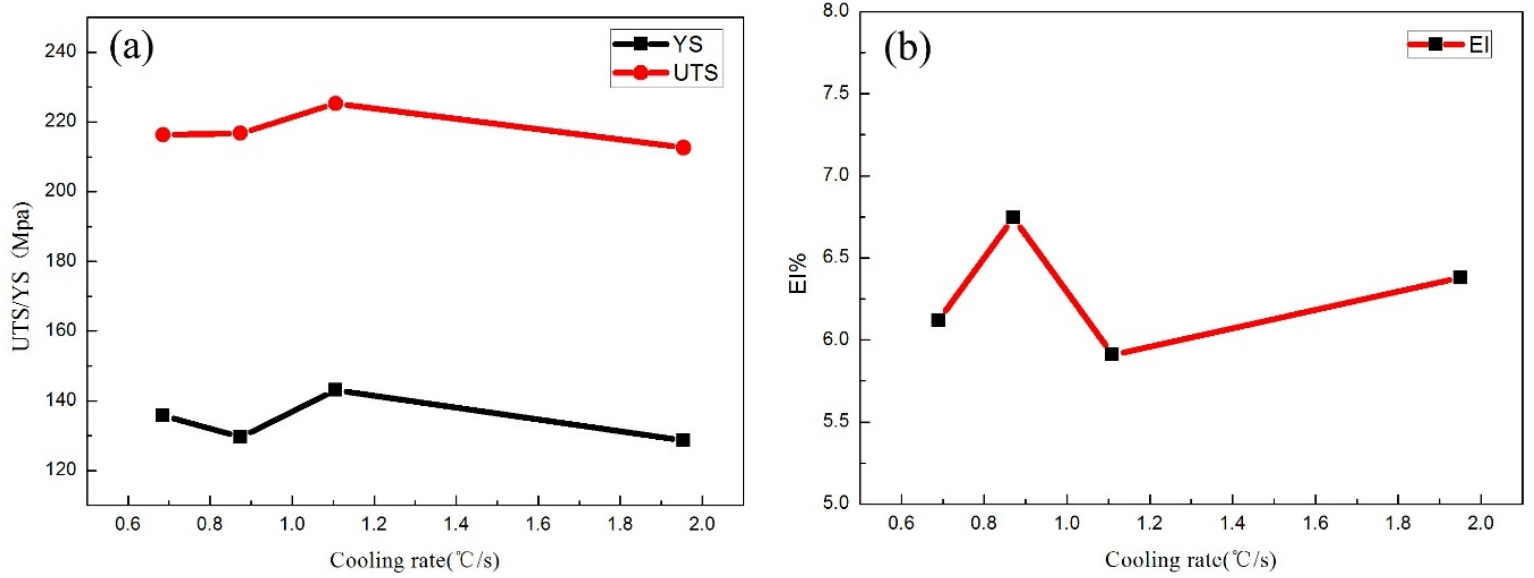

Fig.5. Tensile properties of A356 alloys as a function of cooling rate $\left({ }^{\circ} \mathrm{C} / \mathrm{s}\right)$ 


\section{Discussion}

\section{Effect of cooling rate on iron phase}

In the samples cooled by water cooling method, there are a great number of $\pi$-phases. It is possible that water cooling increases the potential to form Fe-rich intermetallics. As $\alpha$-Al matrix and eutectic Si have low solubility of $\mathrm{Mg}$ and $\mathrm{Fe}$ elements, $\mathrm{Mg}$ and Fe could distribute in the dendrite and interdendritic during solidification, resulting in the formation of intermetallic phases [13]. As a result, the size of Fe-phase increase in the samples cooled by water cooling methods. Besides, the occurrence of peritectic-type reaction transformed the previous $\beta$ phase into $\pi$-phase $[14,15]$. According to Chen et al [16], this transformation phenomenon is observed in solidified microstructures. The chemical reaction could be described as

$\mathrm{L}+\beta-\mathrm{Al}_{5} \mathrm{FeSi} \rightarrow \pi-\mathrm{AlFeMgSi}\left(\mathrm{Al}_{18} \mathrm{Fe}_{2} \mathrm{Mg}_{7} \mathrm{Si}_{10}\right)$.

Thus, the $\pi$-phase can nucleate and then continue to grow on the surface of the $\beta$-platelets through this reaction $[17,18]$.

\section{Effect of cooling rate on tensile properties}

The $\pi$-Fe phase appeared in sample 3 and sample 4 , the sample 4 achieves the best cooling rate and the lowest UTS value, but sample 3 reaches the maximum UTS value. It is possible that the largest cooling rate may cause damage to the sequential solidification theory in the maximum water cooling. Figure. 1 shows that the cooling channel directly influences the spoke solidification. There may occur the local undercooling phenomenon, so that the wheel would not solidify follow an order of inter rim, outer rim, hot spot, spoke, and hub successively. In the maximum water cooling the spoke and outer rim may solidify are firstly. Although the average size of iron phase of sample 4 is smallest (Fig.4), the progressive solidification rule may be destroyed. Therefore, the value of tensile strength increases first but then decreases.

The second best tensile property appears in sample 2, which has similar values with sample 1 . Compared with sample 1 and sample 2, on one hand, as the cooling rate increases, sample 3 has shorter time for the intermetallic particles to grow and coarsen, resulting in small Fe-rich particles (Fig.4) [16]. On the other hand, many $\pi$-Fe phases appeared in sample 3, as mentioned above in the sanction 4.1. The $\pi$-phase can continue to grow on the surface of $\beta$-Fe, preventing further growth of the $\beta$-platelets. As $\beta$-Fe phases is the most detrimental phase for the tensile property, sample 3 exhibits better tensile property because of smaller size of $\beta$-Fe phases . However, the elongation decreases due to the occurrence of Fe-rich phase.

\section{Conclusion}

In this work, the effects of cooling rates on the microstructure and tensile strength of A356 wheels during low pressure die casting process were studied. Results could be concluded as follows:

(1) In the four cooling methods, the cooling rates of two water cooling methods are higher than the other two. In the spokes cooled by water cooling methods, there is more eutectic Si enrichment. Besides, a peritectic-type reaction, which is observed in the solidified microstructure, occurred in the spoke. And the reaction could be given as follows:

$\mathrm{L}+\beta-\mathrm{Al}_{5} \mathrm{FeSi} \rightarrow \pi-\mathrm{AlFeMgSi}\left(\mathrm{Al}_{18} \mathrm{Fe}_{2} \mathrm{Mg}_{7} \mathrm{Si}_{10}\right)$.

(2) Owing to the existence of the $\pi$-AlFeMgSi $\left(\mathrm{Al}_{8} \mathrm{Mg}_{3} \mathrm{FeSi}_{6}\right)$ iron phase and smaller length of iron phase in the microstructure, the best values of UTS and YS under the minimum water cooling condition $(16 \mathrm{~L} / \mathrm{h})$, are $225.27 \mathrm{Mpa}$ and $143.02 \mathrm{Mpa}$, respectively. 


\section{References}

[1] M. Merlin, G. Timelli, F. Bonollo, G. L. Garagnani, Journal of Materials Processing Technology, 2009, 209, (2): 1060-73.

[2] S. Ji, W. Yang, F. Gao, D. Watson, Z. Fan, Materials Science and Engineering A, 2013, $564,130-9$.

[3] WM. Zhao, XF. Jia, ZF. Wang, ZG. Yin, GY. Xiong, Advanced Materials Research, 2011,189-193,4014-7.

[4] P.Skjerpe, Metall. Mater.Trans. A18A, 1987, 189-200.

[5] L.F.Mondolfo, Aluminum Alloys:Structure and Properties, Butter worth, London, 1976, 5-34.

[6] LY. Zhang, BD. Zhou, ZJ Zhan, Materials Science and Engineering A, 2007, 448, 361-365.

[7] A. Dobrzanski, R. Maniara, J. Sokolowski, Journal of Materials Processing Technology, 2007, 191, 317-320.

[8] J. Hemanth, Materials and Design, 1999, 21, 1-8.

[9] Q. G. Wang, D. Apelian, DA. Lados, Journal of Light Metals, 2001, 1, 85-97.

[10] D. Apelian, DA. Lados, Journal of Light Metals, 2001, 1, 73-84.

[11] J. A. Taylor, D. H. Stjohn, J. Barresi, et al, Materials Science Forum, 2000, 331-337, 277-282.

[12] Q. G. Wang, C.H. Cáceres, Materials Science Forum, 1997, 242, 159-64.

[13] R. Chen, YF. Shi, QY. Xu, et al, Transactions of Nonferrous Metals Society of China, 2014, 24, 6, 1645-1652.

[14] A. Verma, S. Kmmar, P. S. Grant, Journal of Alloys and Compounds, 2013, 555, 274-282.

[15] Q. G. Wang, C. J. Davidson, J. Mater, Sci., 2001, 36, pp. 739-50.

[16] HL. Chen, Q. Chen, Y. Du, et al, Transactions of Nonferrous Metals Society of China, 2014, 24, 7, 2041-2053.

[17] LY. Zhang, YH. Jiang, Z. Ma, et al, Journal of Materials Processing Technology, 2008, 207, 1-3, 107-111.

[18] Q. G. Wang, Metallurgical and Materials Transactions A, 2003, 34A, 2887-2889. 